\title{
WHAT DETERMINES THE FLOWERING OF ASTER L., HETEROTHECA CASS., MIYAMAYOMENA KITAM. AND SYMPHYOTRICHUM NEES GENERA PLANTS?
}

\begin{abstract}
Arūnas BALSEVIČIUS, Botanical Garden, Vytautas Magnus University, K. Donelaičio g. 58, LT-44248 Kaunas, Lithuania, arunas.balsevicius@vdu.lt

Sonata KAZLAUSKAITE், Department of Agroecosystems and Soil Sciences, Faculty of Agronomy, Vytautas Magnus University, K. Donelaičio g. 58, LT-44248 Kaunas, Lithuania, sonata.kazlauskaite@ vdu.lt (corresponding author)

Indrė LUKŠYTÉ, Vytautas Magnus University Botanical Garden, K. Donelaičio g. 58, LT-44248 Kaunas, Lithuania, indre.luksyte@vdu.lt

Ričardas NARIJAUSKAS, Botanical Garden, Vytautas Magnus University, K. Donelaičio g. 58, LT-44248 Kaunas, Lithuania, ricardas.narijauskas@vdu.lt

The assortment of ornamental perennial herbaceous plants in Lithuania is growing every year. Spring and summer flowering plants and ornamental plants of the Poaceae family are mainly grown in Lithuania. The first frosts in Lithuania usually occur in SeptemberOctober, when some plants freeze. The aim of this study was to investigate the assortment of perennial herbaceous plants of the latest flowering family Compositae and what climatic factors influence their flowering time and duration. The research was carried out in Vytautas Magnus University Botanical Garden in 2019-2020.
\end{abstract}

Keywords: Compositae, frosts, air temperature, precipitation.

\section{INTRODUCTION}

According to Alisov's climate classification, the territory of Lithuania belongs to the south-western subregion of the Atlantic continental forest area (Alisov, 1969). Lithuania is characterized by 4, 5, 6, 7 USDA climate severity zones (Date of Lithuanian Hydrometeorological Service under the Ministry of Environment). Lithuania is characterized by strong seasonality. The average annual precipitation reaches about $657 \mathrm{~mm}$. The course of seasonal development of plants is influenced by meteorological factors. Plant vegetation usually begins in March-April and ends in November-December. The variety of perennial herbaceous plants that flower in autumn is not large. Plants belonging to the family Compositae, some species and varieties of the genera Persicaria, Hylotelephium, plants of the family Poaceae flower in late autumn mostly. Plants of various other genera flowers for the second time in autumn. However, most of the assortment of the latest flowering plants in Lithuania consists of plants of the Compositae family - namely, plants of the genera Aster, Heterotheca, Miyamayomena, Symphyotrichum.

Compositae is one of the most abundant plant families, with about 32,000 annual, biennial, perennial herbaceous and woody plant species common throughout the world. Until 1833 such genera like Aster (Cayuela, Oksanen, 2016a), Heterotheca (Cayuela, Oksanen, 2016b), Miyamayomena (Cayuela, Oksanen, 2016c), Symphyotrichum (Cayuela, Oksanen, 2016d) were assigned to the same genus Aster. Finally, it was observed that some species of genus Aster are morphologically different from other species and have been assigned to other genera (Nesom, 1994).

The aim of this study was to investigate the assortment of perennial herbaceous plants of the latest flowering family Compositae and what climatic factors influence their flowering time and duration.

\section{MATERIALS AND METHODS}

Botanical names of plants verified according to the system of taxonomic standardization of plant species names (The Plant List, 2013).

The research was carried out in Vytautas Magnus University Botanical Garden in 2019-2020. Phenological observations of plants were performed in accordance with methodological publication prepared by Vaidelys (2005) "Methodology of phenological observations, biometric measurements and assortment formation of ornamental herbaceous plants".

The analysis of autumn flowering plants grown in Lithuania was performed by examining assortment of Lithuanian collectors, nurseries, flower growers, botanical gardens, etc.

Copyright () 2021 The Authors. Published by Vytautas Magnus University. This is an open-access article distributed under the terms of the Creative Commons Attribution License (CC BY 4.0), which permits unrestricted use, distribution, and reproduction in any medium, provided the original author and source are credited. 
Meteorological data of Kaunas Meteorological Station which belongs to the Lithuanian Hydrometeorological Service under the Ministry of Environment were used for the research in 2019 - 2020 (Table 1).

Table 1. Average air temperature and average precipitation in 2019-2020 (data of Kaunas Meteorological Station)

\begin{tabular}{|l|c|c|c|c|}
\hline \multirow{2}{*}{ Month } & \multicolumn{2}{|c|}{ Average air temperature ${ }^{\circ} \mathrm{C}$} & \multicolumn{2}{c|}{ Average precipitation $\mathrm{mm}$} \\
\cline { 2 - 5 } & 2019 & 2020 & 2019 & 2020 \\
\hline January & -4.40 & 2.50 & 58.50 & 52.80 \\
\hline February & 1.10 & 2.20 & 26.80 & 54.90 \\
\hline March & 3.50 & 3.60 & 40.70 & 29.30 \\
\hline April & 9.00 & 6.90 & 0.60 & 9.00 \\
\hline May & 13.10 & 10.50 & 29.90 & 99.40 \\
\hline June & 20.40 & 19.00 & 49.40 & 60.40 \\
\hline July & 17.20 & 16.80 & 60.10 & 92.80 \\
\hline August & 18.20 & 18.60 & 68.20 & 13.30 \\
\hline September & 13.00 & 13.70 & 43.30 & 52.50 \\
\hline October & 9.20 & 10.20 & 46.80 & 30.00 \\
\hline November & 5.00 & 5.20 & 20.50 & 52.80 \\
\hline December & 5.20 & 2.50 & 42.30 & \\
\hline
\end{tabular}

Average air temperatures in 2019 and 2020 were similar. Air temperatures in April, May, June and July in 2019 were $0.4-2.6^{\circ} \mathrm{C}$ higher than in 2020 . Precipitation was higher in 2020 . The first frosts $\left(-1--3^{\circ} \mathrm{C}\right)$ were recorded in the research place on 23 September in 2019 and on 19 October in 2020.

The flowering period of the studied plants lasts from the second decade of September to the second decade of November.

The average air temperature in 2019 was lower comparing with average air temperature in 2020. During the first decade of September and third decade of October, the average air temperature was $9.5^{\circ} \mathrm{C}$ and $7.4^{\circ} \mathrm{C}$. In the second decade of October, the average air temperature was $12.3^{\circ} \mathrm{C}$. Later until middle of November the temperature dropped from $8.1^{\circ} \mathrm{C}$ to $7.2^{\circ} \mathrm{C}$.

In the third decade of September and first decade of October, the average air temperature was $13.7^{\circ} \mathrm{C}$ and $13.4^{\circ} \mathrm{C}$. During the second decade of October, the average air temperature was $7.1^{\circ} \mathrm{C}$. In the third decade of October, the average air temperature was $10.2^{\circ} \mathrm{C}$. In November, the average air temperature dropped from $7.2^{\circ} \mathrm{C}$ to $5.5^{\circ} \mathrm{C}$.

September in 2019 was rainy. The highest amount precipitation fell in the third decade of September (average precipitation was $33 \mathrm{~mm}$ ). Precipitation decreased in October $(28.4 \mathrm{~mm}$ of precipitation fell in the first decade of October and $4.8 \mathrm{~mm}$ in the third decade) $8.4 \mathrm{~mm}$ of precipitation fell in early November and decreased in the second decade of November $(4.1 \mathrm{~mm})$.

The average precipitation was $13.3 \mathrm{~mm}$ in September 2020, and in the last decade of September there was no precipitation at all. The average precipitation in October was $52.5 \mathrm{~mm}$. The highest precipitation registered in the second decade of October $(33.0 \mathrm{~mm})$. At the end of October and until the second decade of November, precipitation decreased from 15.9 to $10.8 \mathrm{~mm}$.

\section{RESULTS AND DISCUSSION}

The earliest varieties of the studied plants began to flower in the third decade of September. All plants flowered massively in the third decade of October. The end of flowering was recorded in the second decade of November (Table 2).

Table 2. Flowering time of studied plants, 2019-2020 (Vytautas Magnus University Botanical Garden)

\begin{tabular}{|c|c|c|c|c|c|c|}
\hline \multirow[t]{2}{*}{ The name of the plant } & \multicolumn{2}{|c|}{$\begin{array}{l}\text { Beginning of the flowering } \\
10 \%\end{array}$} & \multicolumn{2}{|c|}{$\begin{array}{l}\text { Massive flowering } \\
50 \%\end{array}$} & \multicolumn{2}{|c|}{$\begin{array}{l}\text { End of the flowering } \\
10 \%\end{array}$} \\
\hline & 2019 & 2020 & 2019 & 2020 & 2019 & 2020 \\
\hline Aster ageratoides 'Starshine' & 14.10 & 09.10 & 25.10 & 26.10 & 15.11 & 07.11 \\
\hline Heterotheca villosa 'Golden Sunshine' & 07.10 & 05.10 & 23.10 & 23.10 & 06.11 & 01.11 \\
\hline Miyamayomena savatieri 'Variegata' & 09.10 & 05.10 & 23.10 & 23.10 & 13.11 & 09.11 \\
\hline Symphyotrichum cordifolium 'Little Carlow' & 07.10 & 09.10 & 23.10 & 23.10 & 06.11 & 01.11 \\
\hline Symphyotrichum dumosum 'Herbstrot' & 07.10 & 12.10 & 23.10 & 26.10 & 04.11 & 30.10 \\
\hline Symphyotrichum ericoides 'First Snow' & 07.10 & 05.10 & 23.10 & 23.10 & 08.11 & 03.11 \\
\hline Symphyotrichum ericoides 'Golden Spray' & 04.10 & 07.10 & 23.10 & 21.10 & 08.11 & 03.11 \\
\hline Symphyotrichum ericoides 'Weisser Zwerg' & 08.10 & 05.10 & 23.10 & 21.10 & 08.11 & 03.11 \\
\hline Symphyotrichum lateriflorum 'Lady in Black' & 08.10 & 07.10 & 23.10 & 26.10 & 16.11 & 13.11 \\
\hline Symphyotrichum lateriflorum 'Prince' & 04.10 & 12.10 & 21.10 & 23.10 & 08.11 & 03.11 \\
\hline Symphyotrichum novae-angliae 'Kylie' & 08.10 & 05.10 & 21.10 & 23.10 & 08.11 & 03.11 \\
\hline Symphyotrichum novi-belgii 'Kristina' & 28.09 & 26.09 & 21.10 & 23.10 & 04.11 & 30.10 \\
\hline Symphyotrichum novi-belgii 'Magic Blue' & 08.10 & 05.10 & 23.10 & 23.10 & 08.11 & 03.11 \\
\hline $\begin{array}{l}\text { Symphyotrichum novi-belgii 'Professor Anton } \\
\text { Kippenberg' }\end{array}$ & 28.09 & 25.09 & 23.10 & 21.10 & 08.11 & 03.11 \\
\hline Symphyotrichum novi-belgii 'Rosenwichtel' & 08.10 & 05.10 & 23.10 & 23.10 & 08.11 & 03.11 \\
\hline Symphyotrichum 'Ann Leys' & 08.10 & 05.10 & 25.10 & 21.10 & 08.11 & 07.11 \\
\hline Symphyotrichum 'Pink Star' & 08.10 & 05.10 & 23.10 & 23.10 & 08.11 & 03.11 \\
\hline
\end{tabular}


There was no precipitation during the second decade of September in 2020, and the average air temperature was higher than in 2019. Therefore, most of the studied plants started to flower earlier. Massive flowering of plants was hardly affected by air temperature and precipitation because flowering time differed by $1-4$ days. In November 2020, the average air temperature was lower and more precipitation fell compared to 2019. These meteorological factors shortened the flowering time of the studied plants by 1-8 days compared to 2019 .

The duration of the studied plants in 2019 and 2020 was different (Table 3). The flowering duration of 88.20\% of the studied plants was longer in 2019.

Table 3. Duration of flowering of studied plants, 2019-2020 (Vytautas Magnus University Botanical Garden)

\begin{tabular}{|l|c|c|}
\multicolumn{1}{|c|}{ The name of the plant } & \multicolumn{2}{c|}{ Duration of flowering, days } \\
\cline { 2 - 3 } & 2019 & 2020 \\
\hline Aster ageratoides 'Starshine' & 33 & 30 \\
\hline Heterotheca villosa 'Golden Sunshine' & 31 & 29 \\
\hline Miyamayomena savatieri 'Variegata' & 35 & 24 \\
\hline Symphyotrichum cordifolium 'Little Carlow' & 31 & 19 \\
\hline Symphyotrichum dumosum 'Herbstrot' & 29 & 30 \\
\hline Symphyotrichum ericoides 'First Snow' & 33 & 28 \\
\hline Symphyotrichum ericoides 'Golden Spray' & 36 & 30 \\
\hline Symphyotrichum ericoides 'Weisser Zwerg' & 32 & 38 \\
\hline Symphyotrichum lateriflorum 'Lady in Black' & 40 & 23 \\
\hline Symphyotrichum lateriflorum 'Prince' & 36 & 30 \\
\hline Symphyotrichum novae-angliae 'Kylie' & 32 & 35 \\
\hline Symphyotrichum novi-belgii 'Kristina' & 41 & 30 \\
\hline Symphyotrichum novi-belgii 'Magic Blue' & 32 & 32 \\
\hline Symphyotrichum novi-belgii 'Professor Anton Kippenberg' & 32 \\
\hline Symphyotrichum novi-belgii 'Rosenwichtel' & 32 & 34 \\
\hline Symphyotrichum 'Ann Leys' & 32 & 30 \\
\hline Symphyotrichum 'Pink Star' & 32 & \\
\hline
\end{tabular}

$41.2 \%$ of the studied plants flowered for 2 days longer. However, there were varieties that flowered 13 (Symphyotrichum lateriflorum 'Prince'), 10 (Symphyotrichum dumosum 'Herbstrot', Symphyotrichum novi-belgii 'Professor Anton Kippenberg'), and 8 days (Symphyotrichum ericoides 'Golden Spray') longer. Meteorological factors had the least effect on the time and duration of flowering of Symphyotrichum lateriflorum 'Lady in Black' and Symphyotrichum 'Ann Leys'. The time and duration of the flowering of studies plants were not affected by autumn frosts $\left(-1^{\circ} \mathrm{C}--3^{\circ} \mathrm{C}\right)$.

\section{CONCLUSIONS}

1. Higher air temperatures and lower precipitation made the flowering time earlier in 2-8 days.

2. Air temperatures and precipitation did not affect the massive flowering of the studied plants.

3. Low air temperature and precipitation shortened the flowering time of the studied plants by 1-8 days.

4. Autumn frosts $\left(-1^{\circ} \mathrm{C}--3^{\circ} \mathrm{C}\right)$ did not affect the time and duration of the flowering of studied plants.

\section{REFERENCES}

1. Alisov B. P. 1969. Klimat SSSR./Alice B. P. The climate of the USSR.

2. Cayuela L., Oksanen J. 2016a. Taxonomic Standardization of Plant Species Names, Automated standardization of taxonomic names and removal of orthographic errors in plant species names using 'The Plant List' website (www.theplantlist.org). Available at http://www.theplantlist.org/browse/A/Compositae/Aster/ (accessed 13 March 2021).

3. Cayuela L., Oksanen J. 2016b. Taxonomic Standardization of Plant Species Names, Automated standardization of taxonomic names and removal of orthographic errors in plant species names using 'The Plant List' website (www.theplantlist.org). Available at http://www.theplantlist.org/1.1/browse/A/Compositae/Heterotheca/ (accessed 13 March 2021).

4. Cayuela L., Oksanen J. 2016c. Taxonomic Standardization of Plant Species Names, Automated standardization of taxonomic names and removal of orthographic errors in plant species names using 'The Plant List' website (www.theplantlist.org). Available at http://www.theplantlist.org/1.1/browse/A/Compositae/Miyamayomena/ (accessed 13 March 2021).

5. Cayuela L. Oksanen J. 2016d. Taxonomic Standardization of Plant Species Names, Automated standardization of taxonomic names and removal of orthographic errors in plant species names using 'The Plant List' website (www.theplantlist.org). Available at http://www.theplantlist.org/browse/A/Compositae/Symphyotrichum/ (accessed 13 March 2021).

6. Lietuvos hidrometeorologijos tarnyba prie Aplinkos ministerijos. Available at http://www.meteo.lt/lt/klimato-rajonavimas (accessed 13 March 2021). (In Lithuanian)

7. Nesom G. L. 1994. Review of the taxonomy of Aster sensu lato (Asteraceae: Astereae), emphasizing the New World species. Phytologia, Vol. 77 (3), pp. 141-297. 
8. Vaidelys J. 2005. Dekoratyviųjų žolinių augalų fenologinių stebėjimų, biometrinių matavimų ir sortimento sudarymo metodika. Kauno kolegijos leidybos centras, Mastaičiai. (In Lithuanian)

9. The Plant List. 2013. Version 1.1. Published on the Internet. Available at http://www.theplantlist.org/ 